\title{
PENTINGNYA MENJAGA LINGKUNGAN AGAR TETAP BERSIH DAN SEHAT
}

Lingkungan adalah segala hal apapun itu yang terdapat di sekitar kita, menjadi bagian dari keseharian yang memberikan pengaruh baik langsung maupun tidak langsung pada kehidupan. Pentingnya menjaga lingkungan wajib harus kita tanamkan sejak dini. Penebangan hutan secara liar/pembalakan hutan, polusi air dari limbah industri dan pertambangan, polusi udara di daerah perkotaan, dan masalah mengenai rusaknya lingkungan kita khususnya di Indonesia bukan merupakan masalah yang baru lagi, yang seharusnya dibenahi sesegera mungkin. Bagaimana tidak, masalah ini tidak luput dari peran pemerintah dan masyarakat yang harus berdampingan menjaga lingkungan kita ini.

Lingkungan yang merupakan tempat tinggal semua makhluk hidup yang ada di muka bumi, termasuk manusia, hewan, dan tumbuhan harus kita jaga kelestariannya. Lingkungan sangat penting bagi kelangsungan hidup bagi makhluk hidup. Karena apabila lingkungan tidak ada maka manusia, hewan, dan tumbuhan tidak dapat bertahan hidup. Namun, sekarang lingkungan mengalami kerusakan. Itu semua akibat ulah dari manusia yang tidak bertanggung jawab. Contohnya saja seperti menebang pohon secara liar yang tidak diselingi dengan penanaman pohon kembali sehingga hutan menjadi gundul dan tanah tidak dapat menyerap air bahkan pohon tidak dapat menghirup karbondioksida diudara, penambangan batu bara secara terus-menerus yang dapat menyebabkan tanah yang dikeruk semakin habis dan akan rusak, penggunaan kendaraan bermotor dan pendirian industri yang menyebabkan asap pabrik pada rumah kaca sehingga tingginya emisi gas buang diudara yang mengakibatkan polusi udara dan pemanasan suhu dibumi, serta membuang sampah sembarangan yang berdampak buruk pada kehidupan makhluk hidup. Ulah manusia tersebut dapat berakibat fatal, mereka berani mengatasnamakan bisnis dan mengesampingkan lingkungan tanpa memikirkan anak cucu mereka kelak. Mungkin berbuat itu sangat mudah tapi kalau mengembalikannya seperti semula sangat sulit.

Oleh sebab itu, agar bencana alam tidak terulang terus-menerus, kita sebagai manusia yang hidup dimuka bumi yang telah diberikan kekayaan alam yang melimpah, 
seharusnya kita berterima kasih kepada Tuhan dengan cara menjaga dan melestarikan lingkungan ini. Mulai dari sekarang marilah kita membenahi lingkungan kita.

Dalam kehidupan manusia, sungai memiliki peranan penting. Bahkan hampir semua peradaban besar dalam sejarah umat manusia selalu berlangsung di tepi aliran sungai. Sampah-sampah yang mencemari kawasan sungai Batang Arau tersebut berasal dari bekas makanan yang di buang oleh para wisatawan dan pedagang, sampah-sampah rumah tangga dan sisa-sisa bangkai kapal nelayan yang rusak dan karam. Apabila permasalahan sampah tersebut tidak diatasi dengan baik, maka akan timbul permasalahan kerusakan lingkungan di Sungai. Permasalahan lingkungan yang timbul akibat sampah antara lain kerusakan ekosistem sungai, pencemaran yang menyebabkan keracunan, hingga pendangkalan aliran sungai. Demi mencegah semakin parahnya pencemaran yang terjadi maka kesadaran masyarakat yang tinggal di daerah tersebut sangat dibutuhkan rendahnya partisipasi masyarakat dalam menjaga kebersihan sungai disebabkan kebiasaan yang menganggap membuang sampah ke sungai lebih praktis dan mudah. Selain itu, kurang memadainya sarana dan prasarana pembuangan sanpah menyebabkan masyarakat memilih membuang sampah ke sungai.

Kerja bakti membersihkan lingkungan rumahKerja bakti membersihkan lingkungan rumah biasanya dilakukan dalam lingkup rukun tetangga (RT) dan rukun warga (RW). Kerja bakti tersebut dilakukan oleh semua warga dalam lingkup RT dan RW yang bertujuan untuk mencapai lingkungan hidup yang bersih dan asri.

Kerja bakti membersihkan lingkungan biasanya mencakup menyapu jalan, membersihkan gorong-gorong, membersihkan selokan, sungai, dan air yang menggenang, membersihkan halaman rumah, menanam tumbuhan di lingkungan sekitar, dan membersihkan seluruh sampah di lingkungan tersebut.Seluruh warga juga harus bekerja sama untuk tidak membuang sampah secara sembarangan agar kebersihan dan keasrian lingkungan terjaga.

Menjaga lingkungan tetap bersih merupakan hal yang sangat penting. Menjaga lingkungan agar tetap bersih mudah sebenarnya, tapi kadang-kadang penerapannya saja yang sangat untuk dilakukan. Tapi kalau sering dilakukan itu akan membuat kita terbiasa untuk selalu menjaga lingkungan agar tetap bersih. Jika sejak dini kita diajarkan oleh orang tua kita tentang arti sebuah hidup yang sehat maka akan membuat kita terbiasa menjaga lingkungan agar tetap bersih. 
Hal yang kecil yang bisa dilakukan adalah dengan membuang sampah pada tempatnya. Lingkungan yang bersih dan nyaman itu akan membuat hati kita terasa damai. Dan dengan menjaga lingkungan agar tetap bersih itu akan membuat kita jauh dari berbagai macam penyakit.

Berikut adalah Tips Menjaga Lingkungan Agar Tetap Sehat Dan Nyaman.

1. Buanglah sampah pada tempatnya

Buanglah sampah pada tempatnya. Akan lebih baik jika kita membuangnya dengan membedakan sampah basah dengan sampah kering, dan sampah organik dan non organik.

2. Buatlah jadwal piket

Buatlah jadwal untuk membersihkan rumah. Jika kita tinggal di lingkungan yang bersih, maka kita akan lebih merasa nyaman untuk tinggal dan terhindar dari penyakit karena kotoran dan debu.

3. Biasakan membersihkan rumah

Biasakan kita untuk membersihkan kamar, kamar mandi, Dapur, halaman rumah, selokan, dan area sekitar rumah secara rutin.

4. Mensucikan selokan-selokan

Tujuan dari membersihkan selokan adalah agar air di selokan tidak tersumbat oleh sampah-sampah. Jika selokan tersumbat bisa saja menimbulkan aroma yang tidak sehat dan menimbulkan serangga seperti kecoa.

5. Bakar sampah yang tertimbun

Sampah yang sudah dibuang jika sudah banyak digunakan agar tidak berterbangan dan berserakan kembali.

6. Lakukan langkah $3 \mathrm{M}$

Menutup tempat penyimpanan air, Menguras bak mandi secara ritun dan Mengubur barang-barang bekas

7. Selalu menggunakan $3 \mathrm{~B}$

Buang sampah di tempat yang sudah tersedia, Bersihkan segala sesuatu yang kotor dan Biasakanlah untuk hidup sehat dan bersih. 


\section{REFERENSI}

Mutiani, M., Noortyani, R., Tetep, T., Jumriani, J., \& Widyanti, T. (2020). Penguatan Kesadaran Lingkungan Islami melalui Penggalian Puisi sebagai Sumber Belajar IPS. Islam Realitas: Jurnal Kajian Islam dan Sosial , 6 (2), 150-163.

Putra, MAH, Mutiani, M., Jumriani, J., \& Handy, MRN (2020). Pengembangan Bank Sampah Sebagai Bentuk Partisipasi Masyarakat dalam Pengelolaan Sampah. Jurnal Ilmu Sosial Kalimantan , 2 (1), 22-30.

Putro, HPN, Jumriani, J., Darmawan, D., \& Nuryatin, S. (2020). Kehidupan Sosial Masyarakat: Perspektif Masyarakat Tepian Sungai di Sungai Jingah, Banjarmasin. Jurnal IPS Kalimantan , 1 (2), 151-158.

Syaharuddin, S., Handy, MRN, Jumriani, J., Faisal, M., \& Maulana, I. (2020). NilaiNilai Gotong Royong Dalam Kegiatan Sosial BPK di Banjarmasin. Jurnal IPS Kalimantan , 2 (1), 62-68.

Syaharuddin, S., Samihati, M., \& Jumriani, J. (2020). Aktualisasi Sikap Peduli Lingkungan Melalui Aktivitas Pengelolaan Sampah. Jurnal Socius , 9 (2), 193203.

Wijaya, Y. F., \& Muchtar, H. (2019). Kesadaran masyarakat terhadap kebersihan lingkungan sungai. Journal of Civic Education, 2(4), 405-411. 